に対して反対側を予め加熱しておいて收縮させておくと熔接 後歪が相殺されてなくなる。第 366 図にはこの例を示す。T 型に管を熔接すると八狀に歪むが、予熱により歪が除ける

一事が分ら。次に惂之熔接棒の使用法、熔接の技術、鋼管熔接 の実例、板と管とが接合せる隅の部分等こつき說明してるる。

(小林 喜通)

\section{［236] 飛行機構造における熔接技術 (2)}

[Kurt Queitsch, Aircraft Engg.*, 1940-1, Vol. 12, No. 131, 頁 24〜26, 図 11, 表 2]前稿におけら続きで、連続し た管における熔接、愹接鋼管構造におけっ歪等を例に挙げて 說明してるる。

(小林 褻通)

\section{[237］ピストンリング瑇の隅の丸味に就て}

[E. Micke1, Luftwissen, 1939-12, Bd. 6, Nr. 12, 頁 305 〜308, 図 10] 第 367 図に示す様なピストンリング溝隔壁 の破壞が時に見受けられる。これはリング愺隅の丸啋の 適否にも影響される所が大きいものと考へられるので、如何 なる形の丸味が强さ及び工作上の難易の点から見て最もよい かを定めるため に次の様な実驗 を行つた。実驗 に供した溍の阳 の丸味の形は第 368 図に示乙 た。この中 $g$ は 2 簓の円弧によ る丸味である。

先一靜的試驗 としてピスト ンから切出し た、靴の村いて るる板に就て第 369 図の様に荷 重を加へて破壞 試驗を行つた。

第 370 図は一 般に使用される ピストン材料
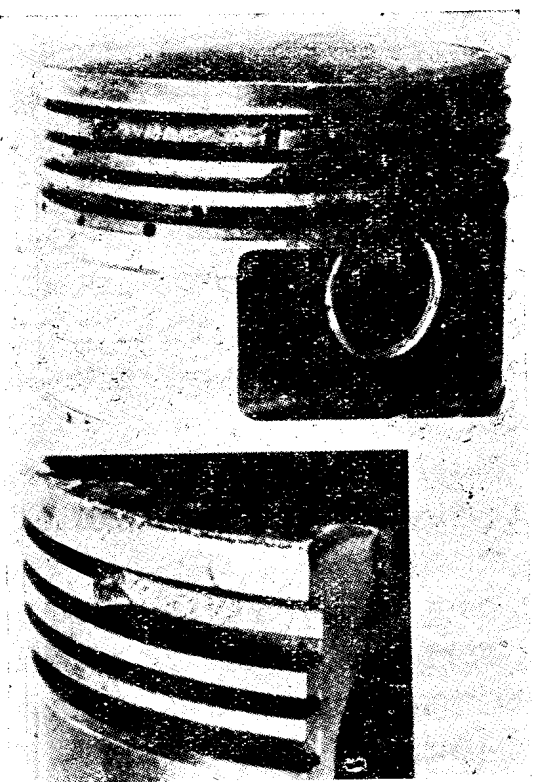

第367図 航営発動機ピストンの リング灌隔壁の破壤例

に対する踭的試騟結果である。数值は破壊に要した荷重であ る。これより明らかな如く、溝の隅の丸味の大きいもの程强 いことが知れる。

光にこの静的試驗の結果から、実際運轉狀態の强さを推測 するために、第 371 図の如き装置により、普通使用する二三 のリング㴖 に就きローゼンハウゼンの $50 \mathrm{t}$ 繰返試驗機 に依て動的疲試驗を行つた。試驗は $1000 \mathrm{~kg}$ からある荷重迄 の間で繰返荷重を加へて、破壞迄の繰返数を測定したもので ある。

第 372 図はこの試驗結果である。これより第 2 図 $g$ の二 つの円弧で作つた丸沬のものが同図 $d$ の $r=1.0 \mathrm{~mm}$ のも
のと强さが殆ど変らない事が分つた。

一般に丸味を付けた隅の附近の應力の分布狀態は第 373 図 に示す通りで $A$ 点におけっ最大應力 $\sigma_{\max }$ がリング靴隔 壁の强さを決定するのである。よつて他の $x$ 点における應

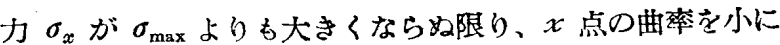

(a)

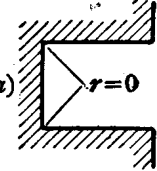

(b)

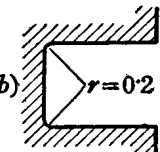

(c)

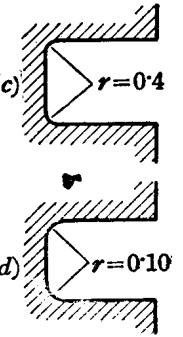

(e)

ても差支ない。第 374 図で明らかな 椂に一つの円弧で大きな丸味を持たせ るより、丸味の曲 率を上記の様に変 化させっ方が場所 を取らなくて済む わけである。

次に工作上の点 からは、磪力の分 布が一様になつて るる様に即ち或强 さで場所の取り方 の最も少い椂に丸 味の曲率を溸変さ せる事は難しいの で、第 375 図の $b$, c に示す樣な双物 を用ひて 2 重冈弧 の丸味にすれば比 較的䉍單に工作出 未第376図に 色々な形の隅の比 較を示す。
(三井 壽雄)
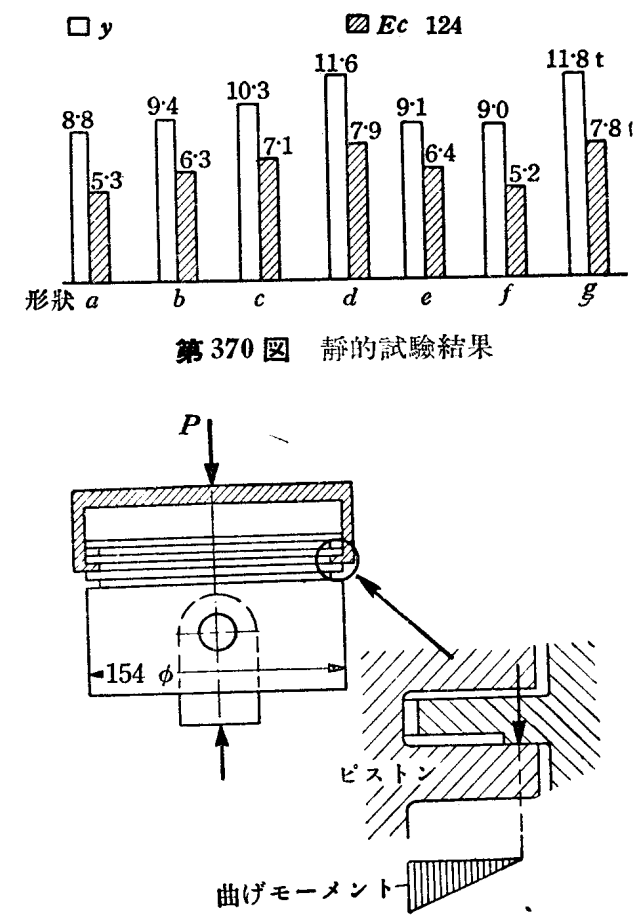

第371 図 動的試驗法図解 


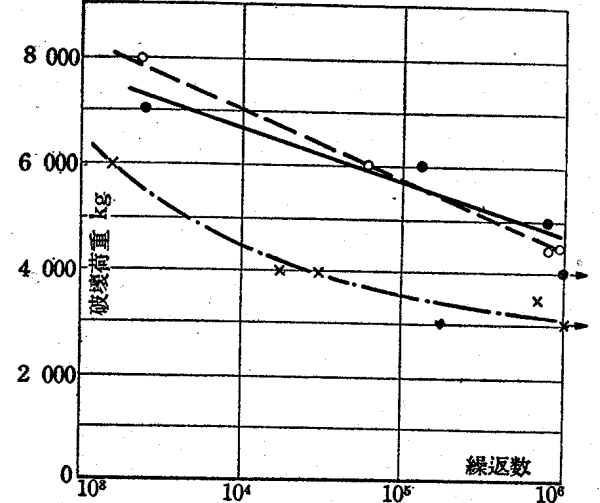

第 372 図 動的試驗結果

$\mathrm{x}=$ 第 358 図 $(b), \quad \cdot=$ 第 368 図 $(d)$, $\circ=$ 第 368 図 $(g), \quad \rightarrow=$ 末破壤
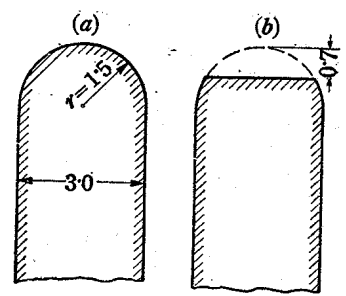

(c)

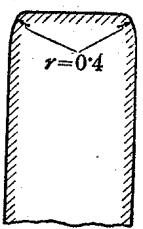

第 375 图 2 䇠の円弧による好味を工作する工具の裴作法

(a)

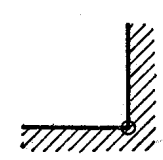

(b)

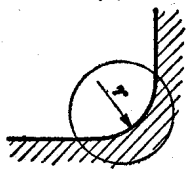

第376 图，各種如味の比較 $(a)=$ 丸味のない場合、 $(b)=1$ 箇の闩弧によるもの、 $(c)=3$ 筒の问弧によるるの

\section{[238］航空発動機の性能の諸概念}

[A. Seifert, Luftwissen, 1939-8, Bd. 6, Nr. 8, 頁 238 〜21, 図 6] 先頃ドイッに於ては、航空発動機に就て今迄 習慣的に使つてるた性能の概念を改革し、新しく而も簡單化 ざれた性能の概念を作り：これに依て外国特に英米における 性能の概念に近づける事が出来る様になつた。ドイッ及び諸 外国の航空発動機の性能を比較した多くの文献には外国の性 能概念に関する 解䆁が不明膫で あつたので少か らざる混乱と誤 解を生じてるた が、著者はこの 点に鑑み、次の 㟢稿に於て、ド イッ及び諸外国 の航空発動機の 性能概念の大要 を示し、ドィッ の性能概念との 比較の可能性あ 昭 利 15 年 6 月了

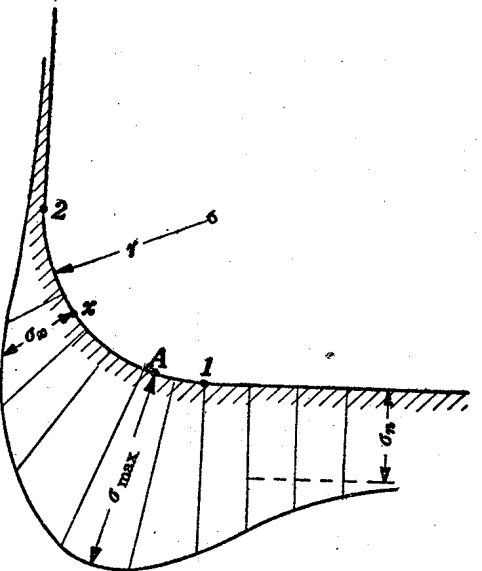

第373图 1 䇠の问弧による丸味 の隅の應力分布狀熱

る事を簡單に結論する。

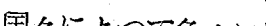

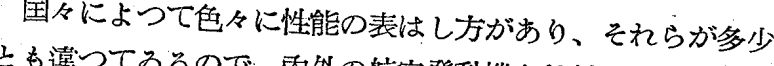
規淮䊗発動機を比較するのに共通 難い。従て性能制定に虽つては、俱断を避ける ために色々な解䆁な知つて置かねばならぬ。

英国一 英国では Air Ministry から発動機の認定馬力と して「国際定格馬力」が提唱されてるるが、これは正規高度 で、国際標淮回轉数で運轉する時の馬力である。正規高度と は国際徱準回轉数に於て絞弁全開及び 正規ブーストで飛び 得る高度であつて、国際醥淮回轉数とは上算飛行中の許容最 大回轉数で、胡間的に制限のない発動機回轉数である。泣て 「国際定格馬力」は最高負何時の出力でもなく、継続運轉時の 馬力でもない一種の認定馬力である。国際標準回轉数の外に 佾最大速度で水本飛行をしてるる時の最大回轉数があるが、 これは $5 \mathrm{mn}$ 以上は要求されぬ。この様な最大回轉数及び許 容最高ブース卜時の出力が 水平行飛行における 最大定格馬 力であつてこれは $5 \mathrm{mn}$ 以上は要求し得ない。この最大定格 馬力を英国の製造者は最大水平飛行馬力 $(5 \mathrm{mn})$ と云心。離 陸封の最大馬力は発動機の出し得る許容最大馬力であつて、 この外にも製造者は最小離昇馬力なるものを提唱するが、離 舁馬力を或一定の特間为上出してはなら公方事は示して ない。2 段過給器付のものでは国際定格馬力及び最大水平飛

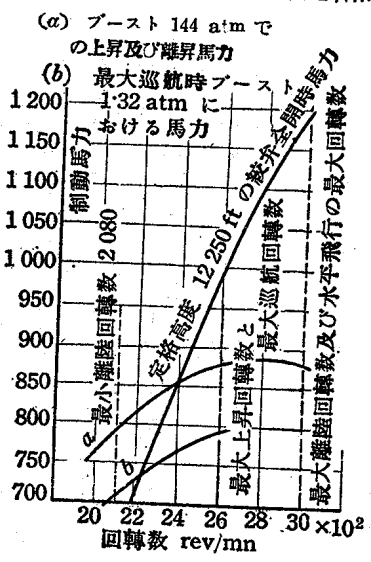

(b)
行馬力は各段に 就て云はれる。 許容最大回轉数 及び巡航時ブー ストによつて、 巡航時馬力と云 へる範囲は膺く、 その上下の限界 は色々に決めら れる。第 377 図 はロールス・ロ イス・マーリン II を例にとつ た英画式の表は 